\title{
Relationship between Employee Motivation and Job Performance: A Study at Universiti Teknologi MARA (Terengganu)
}

\author{
Nur Shafini Mohd Said* \\ Amaleena Syamimie Ezzaty Ahmad Zaidee \\ Ahmad Suffian Mohd Zahari \\ Siti Rapidah Omar Ali \\ Suzila Mat Salleh \\ Universiti Teknologi MARA (Terengganu) \\ *Email: nurshafini@tganu.uitm.edu.my
}

Doi:10.5901/mjss.2015.v6n4s2p632

\section{Abstract}

\begin{abstract}
Motivation is considered as a predictor of job performance. In other words, the determinants of employee job performance were motivation, aptitudes and skill. Thus, motivated employees with high levels of job involvement are considered as important elements to an organization. In this paper, it attempts to measure the effect of employee motivation towards job performance among non-academic staff in Universiti Teknologi MARA Terengganu (UiTMT). A total of 169 respondents were selected from non-academic staff of departments in UiTMT. Three predictors such as individual needs, personal preferences and work environment were found to have medium to strong correlation with the dependent variables namely job performance. The analysis shows that individual needs, personal preferences and work environment are positively and significantly related to job performance. The outcome of the study indicates that UiTMT needs to focus on their motivation aspect, where it can boost up their level of job performance. Finally, research and practical implications of the study are discussed.
\end{abstract}

Keywords: motivation; individual needs; personal preferences; work environment; job performance;

\section{Introduction}

Motivation is important in the organization to boost morale among employees in order to achieve their goals. Motivated employees help the organization to become more success because motivated employees are consistently looking forward to improve their work performance (Ali \& Ahmed, 2009). The outcome from a motivated employee will produce high level of productivity since they are enjoying their work. Therefore, they feel satisfied in the workplace which resulted in lower absenteeism and reducing turnover rate. It is not an easy task especially for the managers to retain highly motivated employees within the organization as they are the valuable assets of the organization to achieve success in the future (Kreisman, 2002). Employees are the human capital to the organizations, and performance of them within an organization which can lead to organizational prosperity or failure (Salleh et al., 2011).

For Universiti Teknologi MARA Terengganu (UiTMT), employee job performance is very important where it will reflect the higher education performance. According to Salleh et al. (2011), this is due to employee performance standards were designed by the regime to quantify the performance of the organizations. This is accepted to be the "backbone" of UiTMT with basic part of guaranteeing that UiTM approaches and projects are actualized successfully and effectively.

The quality of employees is the important influence on performance, thus the person with high motivation level will succeed. In higher education sector, job performance becomes the most important focus of administrators and academicians where the performance level will deteriorate if the level of motivation of employee drops (Salleh et al. 2011). Besides, most administrative in higher education sector including UiTMT will face with a crucial question of what factors influence employee performance. In line with this, there is insufficient empirical information that may control their endeavors in improving overall job performance among employees.

In perspective of assessing employee job performance at the work place, enthusiasm of analyst to lead a study on 
the relationship between employee motivation and job performance among the non-academic staff of departments in UiTMT. Till to date, there is still very little research on job performance in UiTMT and even less empirical research concerning motivation influencing job performance. Hence, there is a need for this study to examine the employee's motivation as the inidicators of job performance among non-academic staff of departments in UiTMT. Consequently, the objective of this study is to investigate the relationships between the employees motivation to decide how these highlights are identified with job performance (Salleh et al., 2011).

\section{Literature Review}

This section looks at the individual needs, personal preferences, work environment, as well as prior researches on job performance.

\subsection{Individual needs}

An individual needs is one of the element in Maslow Theory. According to Wright (2001), if motivation is driven by unsatisfied needs, it is worthwhile for a manager to understand which needs are more important for each employee. Therefore, Abraham Maslow's theory of a needs hierarchy turn out to be important an organization. In fact, key categories such as physical, safety, affection, esteem and self-realization needs the most discussion (Illich, 2000).

In the theory of hierarchy of needs, Maslow claimed that human beings are motivated by unsatisfied needs, and that certain lower needs need to be satisfied before higher needs can be satisfied. A study by Sarma and Huek (2004) argued that there are general types of needs namely physiological, safety, love and esteem that must be satisfied before a person can act unselfishly. He called these needs as "deficiency needs." As long as individual is motivated to satisfy these needs, he is on the right path to self grow and become self-actualization, once all of the deficiency needs are met.

\subsection{Personal preferences}

Failure to fulfil the competence requirements as well as assignments contrary to employee preference may lead to employee demotivation. Moreover, the consideration of competence preferences may motivate employees because they are normally more motivated to complete tasks related to their interests and abilities motivation (Peters \& Zelewski, 2007).

Personal preferences is basically the feeling of wanting or liking either something or someone more than anyone else. When it comes to work, employees have their own personal preferences that they think could motivate them more at the workplace. Whenever employees are feeling highly motivated, it could directly affect their work performance at workplace. There are so many alternatives that could possibly adopted by manages to boost the morale of their employees such as giving out reasonable salary and payment, create working environment that is conducive or provide them with training or job development (Lange \& Houran, 2010).

Another possible thing that could turn out unmotivated employees to highly motivated employees is by paying attention to the reward system as it is believe as tools that can increase the level of work performance among employees (Cohen et al., 2013). Good reward system is one of the personal preference that employee think could benefits them and motivate them as well. Many organizations around the world are now focusing on improving reward system such as increasing the salary, giving out promotions, bonuses or other types of rewards. It can encourage the employees to be more motivated, and thus increase their quality of work performance (Subramani, 2001).

\subsection{Work environment}

According to Ollukkaran and Gunaseelan (2012), management's new challenge is to create a work environment that entices and inspires its workforce, because the quality of workplace environment affects the level of motivation and employees performance. No doubt, workplace4 environment influences productivity, morale, and employee's engagement-both positive and negative. When employees are physically and emotionally have the desire to work, then their performance shall be increased. It is the quality of the employees' workplace environment that impacts their level of motivation and subsequent performance (Leblebici, 2012). In addition, the qualities of environment in workplace determine the level of employee's motivation and subsequent performance (Naharuddin \& Sadegi, 2013).

Moreover, proper workplace environment helps reduce absenteeism and thus increase employee's performance which wills leads to increase productivity (Peters \& Zelewski, 2007). Peoples working under inconvenient conditions may 
end up with low performance and face occupational health risks causing high absenteeism and turnover (Naharuddin \& Sadegi, 2013). Oladipo (2009) states that suitable environments, often resulting in high worker turnover rate and they will live up to their potential. Job and work environment stimuli were defined as job and workplace characteristics that affected individual workers on a daily basis while doing their jobs in their work environment (Chandrasekar, 2009).

Another research found that improving the working environment reduces complaints and absenteeism while increasing productivity. According to Naharuddin and Sadegi (2013), in recent years, employees comfort while working, due to workplace conditions and environment has been recognized as an important factor for measuring their productivity. Kossek et al. (2012) states that management maximizes employee productivity center around two major areas: personal motivation and the infrastructure of the working environment. El-Sabaa (2001) stressed that in healthy working environments, employees feel engaged in their jobs and also in their home lives. They believe that they are valued at work and their jobs are a good fit with their abilities and interests.

According to Chandrasekar (2009), an extrinsic factor of motivation, work environment has been referred not only to the physical environment but also to emotional aspects of it which has included relationships with supervisors, relationships with co-workers, job-person match, equity and fairness, and personal control of job. Kossek et al. (2012) argued that it is the quality of the employees' workplace environment that most impacts on their level of motivation and subsequent performance. Therefore, creating a healthy work environment would motivate the employees to make an effort at the workplace and thus could increase their work performance.

\subsection{Job performance}

Oluseyi and Ayo (2009) argued that job performance is related to the willingness and openness to try and achieve new aspects of the job which in turn will bring about an increase in the individual's productivity. Job performance can be defined as "all the behaviors employees engage in while at work". Khan et al. (2009) stated that a fair amount of the employees' behavior displayed at work is not necessarily related to job-specific aspects. A good employee performance is necessary for the organization, since an organization's success is dependent upon the employee's creativity, innovation and commitment (Kreisman, 2002).

Job performance refers to how well someone performs at his or her work. Job performance has been defined as work performance in terms of quality and quality expected from each employee (Khan et al., 2009). Besides, Chaudhary and Sharma (2012) defined job performance as the behavior executed in line with the set objectives of the organization. Crucial in a high job performance is the ability of the employee himself (Salanova et al., 2005).

\subsection{Relationship between employee motivation and job performance}

Motivation is an employee's intrinsic enthusiasms about and drive to accomplish activities related to work. According to (Chaudhary \& Sharma, 2012), motivation is the interior drive that causes a person to decide to take action. Now and then managers neglect to comprehend the significance of inspiration in fulfilling their central goal and vision. Actually when they comprehend the essentialness of motivation, they do not have the expertise and learning to give a workplace that can cultivates employee motivation.

Employee motivation is a process whereby one individual has the willingness to fulfil their needs. Individual needs can be in term of survival needs, safety, social, esteem and self-actualization. This need will lead the individual to perform batter in their career in the simple they can perform in their job performance. Performance can be on their customers, salary or others. Chaudhary and Sharma (2012) argued that motivated employees are inclined to be more productive than non-motivated employees If employee is satisfied and happy, then he/she will do his/her work in an extremely amazing manner. The result will be good, and to add motivated employee will motivate other employees in office.

Chaudhary and Sharma (2012) states that, study shows that the employee motivation has direct effect on gainfulness and development. A highly motivated employee tries his or her best in carrying out each and every aspect of his or her duties and responsibilities. Improved job performances of the employee will increase the value to the organization itself and to the employee's productivity.

In order to increase work effectiveness and performance, it is important to address a number of issues, including increasing motivation among employees, making them feel satisfied with their job and increasing their-job related wellbeing in general (Bogdanova \& Naunivska, 2008). A motivated person has the familiarity with particular goals must be accomplished in particular ways, according on how he or she coordinates the push to attain that such goals (Owusu, 2012). It means that motivated person is best fit for the goals that he/she wants to achieve, as he/she is fully aware of its assumptions. Therefore, when workers are motivated, their ability to increase productivity will be high (Ali and Ahmed, 
2009). Employees' motivation is one of the policies managers take to increase effectual job amongst employees in organizations (Olluseyi \& Ayo, 2009).

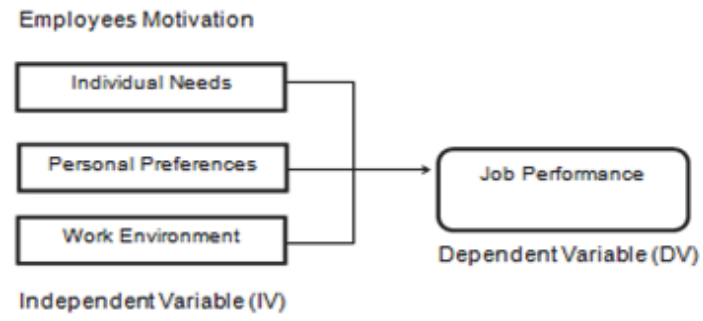

Figure 1. Conceptual Framework of Relationship between Independent Variables and Dependent Variable

\subsection{Hypotheses development}

H1: Individual needs is positively related to Job Performance

$\mathrm{H} 2$ : Personal preferences is positively related to Job Performance

$\mathrm{H} 3$ : Work environment is positively related to Job Performance

\section{Research Methodology}

\subsection{Research design}

The study was led particularly to investigate the influence of job satisfaction and interpersonal trust on Organizational commitments. To attain the objective of the study, a quantitative correlation research design was used to investigate the relationship between the two types of variables.

\subsection{Instrument}

A questionnaire was designed to serve as the main instrument of this study. The items in the questionnaire were formulated according to research objectives and research questions stipulated in this study, supported by literature review references. A set of questionnaire was distributed by hand to the respondents to get the responses in a timely manner. The questionnaire was divided into three sections which were section A, B and C. Section A covered the demographic questions of respondents, whereas section $B$ covered the dependent variable and lastly section $C$ until $F$ covered the independent variables. The questions in section B and C were instructed in Likert-scale format, where number 1 represented strongly disagree, 2 for disagree, 3 is uncertain, 4 is agree and 5 represented strongly agree.

\subsection{Sampling frame}

A comprehensive list of number of the non academic staff at UiTMT, serves as the sampling frame in the study. The company size in the sampling frame, measured in number of employees, which are 200 employees.

\subsection{Sampling technique and process}

The sampling technique that has been used in this study is probability sampling technique which is simple random sampling. Simple random sampling means each member of the population has an equal probability of being selected to be part of the sample. Since each member of the population has the same chance of being selected, this makes the process fair as the resulting samples are very representative of the population. By using this technique, all non academic staff at UiTMT, have the equal chance of being selected for the sample. A total of 200 questionnaires were distributed to the non-academic staff at UiTMT. For the purpose of collecting data, self-delivered and post approaches had been used. All the data obtained were analyzed through the Statistical Package for the Social Sciences (SPSS) statistical packet program and three proposed relations were tested through regression analyses 


\section{Findings and Discussion}

\subsection{The overall motivation of job performance}

This study discussed three variables namely individual needs, personal preferences, and work environment that influence job performance. The summary of the demographic compositions of the respondents are shown in Table 1. Descriptive analysis of demographic information indicated that most of the respondents were male with the percentage of $49.7 \%$ while $50.3 \%$ were female. The age groups were $34.3 \%$ with age between 21 to 30 years old, $34.9 \%$ with age between 31 to 40 years, and $20.1 \%$ with age 41 to 50 years and $10.7 \%$ were above 51 years old. Based on the education background, most of them were Sijil Pelajaran Malaysia holders $50.9 \%$ followed by $34.9 \%$ diploma, $7.7 \%$ degree, and $1.8 \%$ others. Respondents with Master qualification were only $4.7 \%$. The percentage of respondents who were categorized with working experiences of below 1 year were 10.7\%, 1-5 years were 32.5 while those who have working experience between 6 to 10 years were $32.5 \%$. Table 1 also shows that $25.4 \%$ of the respondents are attached with the registry department, $22.5 \%$ with student affairs, $11.2 \%$ with Library, 9.53\% with Treasury, $8.3 \%$ with Rector Office and $23.1 \%$ with no specific department. In addition, the majority of monthly salary is between RM1000 to RM 1999 (45\%), $32.5 \%$ earn between RM2000-2999, 11.8\% have their income between RM3000-3999, 7.7\% earn more than RM4000 and $3.0 \%$ earn less than RM1000.

Table 1. Respondents' Demographic Profile

\begin{tabular}{|c|c|c|c|c|}
\hline No & Profile & Description & Responses & Percentage \\
\hline 1 & Gender & \begin{tabular}{|l|} 
Male \\
Female
\end{tabular} & $\begin{array}{l}84 \\
85\end{array}$ & $\begin{array}{l}49.7 \\
50.3\end{array}$ \\
\hline 2 & Age & \begin{tabular}{|l}
30 years old and below \\
$31-40$ \\
$41-50$ \\
51 and above
\end{tabular} & $\begin{array}{l}58 \\
59 \\
34 \\
18\end{array}$ & $\begin{array}{l}34.3 \\
34.9 \\
20.1 \\
10.7\end{array}$ \\
\hline 3 & Departments & $\begin{array}{l}\text { Rector Office } \\
\text { Treasury } \\
\text { Registry } \\
\text { Library } \\
\text { Students Affairs } \\
\text { Others }\end{array}$ & $\begin{array}{l}14 \\
16 \\
43 \\
19 \\
38 \\
39\end{array}$ & $\begin{array}{c}8.3 \\
9.5 \\
25.4 \\
11.2 \\
22.5 \\
23.1\end{array}$ \\
\hline 4 & Highest Education Level & $\begin{array}{l}\text { SPM } \\
\text { Diploma } \\
\text { Bachelor's Degree } \\
\text { Master's Degree \& above } \\
\text { Others }\end{array}$ & $\begin{array}{c}86 \\
59 \\
13 \\
8 \\
3\end{array}$ & $\begin{array}{l}50.9 \\
34.9 \\
7.7 \\
4.7 \\
1.8\end{array}$ \\
\hline 5 & Monthly Salary & $\begin{array}{l}\text { Below RM1000 } \\
\text { RM1001-RM1999 } \\
\text { RM2000-RM2999 } \\
\text { RM3000-RM3999 } \\
\text { RM4000 and more }\end{array}$ & $\begin{array}{c}5 \\
76 \\
55 \\
20 \\
13\end{array}$ & $\begin{array}{c}3.0 \\
45.0 \\
32.5 \\
11.8 \\
7.7 \\
\end{array}$ \\
\hline 6 & Years of experience & $\begin{array}{l}\text { Less than } 1 \text { year } \\
1 \text { to } 5 \text { years } \\
6 \text { to } 10 \text { years } \\
\text { More than } 10 \text { years }\end{array}$ & $\begin{array}{l}18 \\
55 \\
54 \\
42\end{array}$ & $\begin{array}{l}10.7 \\
32.5 \\
32.0 \\
24.9\end{array}$ \\
\hline
\end{tabular}

\subsection{Correlation analysis result}

Table 1 illustrates the relationships between Job Performance, Individual Needs, Personal Preferences and Work Environment. Spearman's correlation was used to describe the strength and direction of the linear relationship between two variables (Cohen et al., 2013). The values of the correlation coefficients (rho) tabulated in Table 1 indicate the strength of the relationship between variables. The relationships between Job Performance, Individual Needs, Personal Preferences and Work Environment were investigated by using Spearman's correlation coefficient. The results show that there was a strong positive correlation between job performance and work environment $(r=0.724, p<0.05)$. The 
correlation between job performance and personal preferences is $r=0.651$ and $p<0.05$. Besides, the correlation between job performance individual needs is $r=0.60$ and $p<0.05$.

Table 2. Correlation Analysis Result

\begin{tabular}{|c|l|c|c|c|c|}
\hline No & Variables & 1 & 2 & 3 & 4 \\
\hline 1 & Individual Needs & 1.00 & & & \\
\hline 2 & Personal Preferences & $0.694^{*}$ & 1.00 & & \\
\hline 3 & Work Environment & $0.623^{*}$ & $0.710^{*}$ & 1.00 & \\
\hline 4 & Job Performance & $0.600^{*}$ & $0.651^{*}$ & $0.724^{*}$ & 1.00 \\
\hline
\end{tabular}

Notes: ${ }^{*}$ correlation is significant at the 0.01 level (2-tailed); * ${ }^{*}$ correlation is significant at the 0.05 level (2-tailed); Cronbach's alphas in the parentheses along the diagonal

\subsection{Regression analysis}

Further investigation using multiple regression analysis was conducted. A summary of multiple regression analysis for all factors towards dependent variable is displayed in Table 2. In testing the hypothesis 1, 2 and 3, a regression analysis (multiple regression) was performed with individual needs, personal preferences, and work environment as the independent variables and job performance to use as the dependent variable.

To strengthen the evidences, the researcher analyzed the value of R, R-square with Durbin and Watson where it indicates the relationship between independent variables towards dependent variable. The R-value for the variables is 0.759 . It also demonstrated that the value R-square is 0.575 . The results reveal that the three elements namely individual needs, personal preferences, and work environment explained $57.5 \%$ of the variance in job performance. Therefore, $\mathrm{H} 1$, $\mathrm{H} 2$ and $\mathrm{H} 3$ are supported. According to Salanova et al. (2005), Durbin-Watson statistic is a test statistic used to detect the presence of autocorrelation in residuals from a regression analysis. The values below 2 represent positive serial correlation among the errors and values above 2 represent negative serial correlation. Thus, the finding indicates the Durbin-Watson statistic with 1.866 which represents the positive serial correlation.

Table 3. Regression Analysis (Multiple Regression) $(\mathrm{N}=169)$

\begin{tabular}{|c|c|c|c|c|c|}
\hline Model & R & R-Square & F Value & Durbin-Watson & Sig Val \\
\hline 1 & .759 & .575 & .642 & 1.866 & .000 \\
\hline
\end{tabular}

\section{Concluding Remarks}

This study has identified the relationship between employee motivation and job performance among non academic staff in UiTMT. This study proposes and finds that employee motivations can be a valuable tool in measuring the level of job performance among the non academic staff in UiTMT.

Firstly, the study has substantiated the relationship between individual needs, personal preferences, and work environment towards job performance among the non academic staff. The findings supported three hypotheses generated for this study. The study has also contributed to a more comprehensive understanding of the determinants of individual needs, personal preferences, and work environment towards the job performance among non academic staff. Individual needs, personal preferences, and work environment has emerged as key determinants in influencing the job performance among the non academic staff.

From this study, it shows that motivation is important to the employees as it can boost up their level of job performance. In order to sustain their employees in the organization, it is important for the management of UiTM to understand and be aware of the needs of their employees, in their work environment. Besides, the level of job performance are depends both on the management and the employee itself on how they interact and depend on each other through providing individualized support and encouragement to each and every employee by understanding their individual needs, personal preferences, and provide a good work environment. Therefore, there will be a maximum performance and minimum turnover among the employees. Lastly, this study is intended to promote a better theoretical understanding and recognition of the complexities associated with overall job performance. Moreover, it can contribute significantly towards future theoretical advancements in higher education sector models. 


\section{References}

Ali, R., \& Ahmed, M. S. (2009). The impact of reward and recognition programs on employee's motivation and satisfaction: An empirical study. International Review of Business Research Papers, 5, 270-279.

Bogdanova, A., Enfors, H., \& Naumovska, S. (2008). Work environment stressors-The link between employees' well-being and job performance? (Bachelor dissertation, Jönköping University, 2008).

Chandrasekar, K. (2011). Workplace environment and its impact on organisational performance in public sector organisations. International Journal of Enterprise Computing and Business Systems, 1, 1-16.

Chaudhary, N., \& Sharma, B. (2012). Impact of employee motivation on performance (productivity) private organization. International Journal of Business Trends and Technology, 2, 29-35.

Cohen, J., Cohen, P., West, S. G., \& Aiken, L. S. (2013). Applied multiple regression/correlation analysis for the behavioral sciences. (3rd ed.). Oxford: Routledge.

El-Sabaa, S. (2001). The skills and career path of an effective project manager. International Journal of Project Management, $19,1-7$.

Illich, I. (2000). Disabling professions. (1st ed.). London: Marion Boyars Publishers Ltd.

Lange, R., \& Houran, J. (2010). A transliminal view of intuitions in the workplace. North American Journal of Psychology, 12, 501-516.

Leblebici, D. (2012). Impact of workplace quality on employee's productivity: Case study of a bank in Turkey. Journal of Business, Economics and Finance, 1, 38-49.

Khan, R., Rehman, A. U., \& Yousuf, I. (2009). Influence of transformational leadership on employee's performance: A Pakistani perspective. International Journal of Accounting Information, 2, 53-60.

Kossek, E. E., Kalliath, T., \& Kalliath, P. (2012). Achieving employee wellbeing in a changing work environment: An expert commentary on current scholarship. International Journal of Manpower, 33, 738-753.

Kreisman, B. J. (2002). Identification of the drivers of employee dissatisfaction and turnover. (Doctoral dissertation, University of Texas, 2002).

Naharuddin, N. M., \& Sadegi, M. (2013). Factors of workplace environment that affect employees performance: A case study of Miyazu Malaysia. International Journal of Independent Research and Studies, 2, 66-78.

Oladipo, S. E. (2009). Psychological empowerment and development. Edo Journal of Counselling, 2, 118-126.

Ollukkaran, B. A., \& Gunaseelan, R. (2012). A study on the impact of work environment on employee performance. Namex International Journal of Management Research, 2, 70-85.

Oluseyi, S., \& Ayo, H. T. (2009). Influence of work motivation, leadership effectiveness and time management of employees'performance in some selected industries in Ibadan, Oyo State, Nigeria. European Journal of Economics, Finance and Administrative Sciences, $16,1450-2887$.

Owusu, T. (2012). Effects of motivation on employee performance: A case study of Ghana commercial bank, Kumasi zone. (Doctoral dissertation, Kwame Nkrumah University of Science and Technology, 2012).

Peters, M. L., \& Zelewski, S. (2007). Assignment of employees to workplaces under consideration of employee competences and preferences. Management Research News, 30, 84-99.

Salanova, M., Agut, S., \& Peiro, J. M. (2005). Linking organizational resources and work engagement to employee performanceand customer loyalty: the mediation of service climate. Journal of Applied Psychology, 90, 1217-1227.

Salleh, F., Dzulkifli, Z., Abdullah, W. A. W., \& Yaakob, N. H. M. (2011). The effect of motivation on job performance of state government employees in Malaysia. International Journal of Humanities and Social Science, 1, 147-154.

Sarma, A., \& Hoek, A. V. D. (2004). A need hierarchy for teams. (Department of Informatics Donald Bren School of Information and Computer Sciences University of California Irvine, ISR Technical Report: UCI-ISR-04-9, 2004). [Online] Available: http://cse.unl. edu/ asarma/papers/maslow.pdf

Subramani, S. P. V. (2011). A study on link between workplace environment and employee performance at big bazaar, Chennai. (Master dissertation, Sona College of Technology, 2011).

Wright, B. E. (2001). Public sector work motivation: A review of the current literature and a revised conceptual model. Journal of Public Administrative Research and Theory, 11, 559-586. 